Agrovoc descriptors: prunus avium, prunus cerasus, cherries, extracts, antioxidants, phenolic compounds, aromatic compounds, chemical composition, proximate composition

Agris category code: F60

\title{
Relation of total antiradical activity and total polyphenol content of sweet cherries (Prunus avium L.) and tart cherries (Prunus cerasus L.)
}

\author{
Silvia MELICHÁČOVÁ ${ }^{1}$, Mária TIMORACKÁ ${ }^{1}$, Judita BYSTRICKÁ ${ }^{1}$, Alena VOLLMANNOVÁ ${ }^{1}$, Juraj ČÉRY $^{1}$
}

Received January 27, 2010; accepted March 2, 2010.

Delo je prispelo 27. januarja 2010, sprejeto 2. marca 2010.

\begin{abstract}
In present study the quantification of total phenolics content (TPC), total antioxidant activity (TAA) and their relation in sweet and tart cherries were studied. Aqueous and pure polar solvents were used to compare the yield of present phenolic compounds in prepared extracts. The solubility of phenolics was the most effective in sweet cherry extracts with using of $50 \%$ methanol and in tart cherry extracts with using of $50 \%$ acetone. The yield of TPC of both tested cherry fruit extracts was higher with pure methanol in comparison to pure acetone.

Substantial TPC assessed with Folin-Ciocealteu assay in tart cherry extracts were in range from $70.6 \pm 8.46 \mathrm{mg}$ to $241.4 \pm 7.26 \mathrm{mg} \mathrm{GAE} / 100 \mathrm{~g} \mathrm{FW}$. Extracts from lyophilised tart cherries (methanolic and water-acetone mixtures) contain in average 2-times higher amount of polyphenols than ethanol extracts. The DPPH antiradical efficiency values of the both tested fruit extracts were higher in extracts of tart cherries (from 5.4 to $9.9 \%$ of inhibition of DPPH radical) when compared to those of sweet cherries (from 2.4 to $3.5 \%$ of inhibition of DPPH radical). Total antioxidant activity (TAA) of sweet cherry extracts (using $70 \%$ ethanol and with $70 \%$ methanol) and of tart cherry extracts (with $50 \%$ methanol) depended on phenolics content.
\end{abstract}

Key words: total phenolics, sweet cherries, tart cherries, total antioxidant activity

\section{IZVLEČEK}

\author{
POVEZAVA MED ANTIOKSIDANTNO \\ AKTIVNOSTJO IN VSEBNOSTJO VSEH \\ POLIFENOLOV PRI ČEŠNJAH
}

(Prunus avium L.) IN VIŠNJAH (Prunus cerasus L.)

Pri tej raziskavi je bila proučevana celotna vsebnost polifenolov (TPC), celotna antioksidantna aktivnost (TAA) in povezava med njima pri češnjah in višnjah. Uporabljeni so bili vodni ekstrakti in ekstrakti s polarnimi topili ter primerjana vsebnost ekstrahiranih fenolnih snovi. Ta je bila največja pri češnjah, ekstrahiranih s $50 \%$ metanolom in pri višnjah z uporabo $50 \%$ acetona. TPC je bilo več pri češnjah ekstrahiranih s $100 \%$ metanolom, v primerjavi z acetonom. TPC ugotovljeni s Folin-Ciocealteu-jevim reagentom so pri višnjah dali vrednosti od $70,6 \pm 8,46 \mathrm{mg}$ do $241,4 \pm 7,26 \mathrm{mg}$ GAE/100 g sveže teže. Ekstrakti liofiliziranih višenj so pri ekstrahiranju $\mathrm{z}$ metanolom ali mešanico vode in acetona $\mathrm{V}$ povprečju vsebovali dvakrat višjo količino polifenolov kot etanolni ekstrakti. Antioksidativna učinkovitost DPPH je imela višje vrednosti pri višnjah (od 5,4 do 9,9 \% inhibicija DPPH radikalov) v primerjavi z ekstrakti pri češnjah (od 2,4 do 3,5 \% inhibicije DPPH radikalov). Celotna antioksidativna aktivnost (TAA) ekstraktov češenj (z uporabo $70 \%$ etanola in $70 \%$ metanola) in pri ekstraktih višenj (s $50 \%$ metanolom) sta odvisni od vsebnosti fenolnih snovi.

Ključne besede: skupni fenoli, češnje, višnje, celotna antioksidativna aktivnost

\section{INTRODUCTION}

Commonly consumed raw materials of plant origin are the most important sources of phenolic compounds from a health standpoint and from the aspect of consumption by the whole population.
Due to reported epidemiological studies providing data about correlations between fruit consumption and reduced risk of chronic diseases (He et al., 2007), fruits have gained an important place in human nutrition. The combination of vitamins, fibre, phenolics and other

\footnotetext{
1 Department of Chemistry, Slovak University of Agriculture in Nitra, Department of Chemistry, Slovak University of Agriculture in Nitra, e-mail address: melichac@afnet.uniag.sk
} 
antioxidants are probably reliable for these effects (Ruxton et al., 2006). Parallel with this recognition, the consumption of fruits has increased all over the world.

Sweet and tart cherries are natural sources of antioxidants influencing the incidence of degenerative diseases. Mentioned stone fruits from family Rosaceae and genus Prunus have been part of the human diet for several thousands year. Both sweet and tart cherries are widely grown in Slovakia. Local people from some regions have been using sweet and tart cherry fruits as fresh fruit, also for jams, marmalade and compote preparation. In spite of their short consumption period, they are very preferable.

Sweet cherry (Prunus avium L.) contains besides water, saccharides, vitamins A, B and C, pectin, organic acids, also minerals mainly potassium, magnesium, phosphor and calcium (Kalyoncu et al., 2009). Sweet cherries are from ancient times associated with better function of organism and for instance, Wang et al. (1999) reported that the consumption of sweet cherries alleviates arthritis and gout-related pain. Reduction of the proliferation of human colon cancer cells (Kang et al., 2003) has been specifically associated with the consumption of cherries (Serrano et al., 2005).

Recently, also tart cherries with their health benefits have been preferred with unique composition of anthocyanins and related polyphenolics (Gao and
Mazza, 1995; Kim et al., 2005; Piccolella et al., 2008). Tart cherry fruits (Prunus cerasus L.) contain also phenolic acids and quercetin (Seeram et al., 2001; Seymour et al., 2008).

Polyphenolic compounds found in fruit contribute to total antioxidant activity. The large group of plant polyphenols attracts major interest because of their potential antioxidant properties presumably based on their function of natural free radicals scavengers (Sellappan et al., 2002). Although many studies on the phenolics contents of plant sources have been reported from different countries, data about the relations between their amount and antioxidants activity are still insufficient.

In this paper polyphenolic compounds contents and antiradical activity have been quantified in sweet cherry and tart cherry fruits samples grown in Slovakia. Correlations between polyphenolic compounds and total antioxidant activity were evaluated.

The objective was to survey also the effect of pure and aqueous organic solvents and extraction times on the yield of polyphenols from sweet and tart cherry extracts. Efficiency of extractions was tested using the following extraction solvents: water, methanol $(100 \%, 70 \%, 50$ $\% \mathrm{v} / \mathrm{v})$, ethanol $(70 \%, 50 \% \mathrm{v} / \mathrm{v})$, acetone $(100 \%, 70$ $\%, 50 \% \mathrm{v} / \mathrm{v}$ ) and two different time duration of extractions (1h, $8 \mathrm{~h})$.

\section{MATERIALS AND METHODS}

Chemicals as Folin-Ciocalteau assay, gallic acid were purchased from Merck (Germany). Sodium carbonate, methanol, ethanol were obtained from Sigma (USA) and 2,2diphenyl-1-picrylhydrazyl radical from Organics (USA).

\section{Preparation of the samples}

Sweet and tart cherry fruits (unknown cultivars) were obtained from local market in mature stage in June 2009. The fruits were selected, pitted and processed for laboratory analyses.

Organic solvents: methanol $(100 \%, 70 \%$ and $50 \% \mathrm{v} / \mathrm{v})$, ethanol $(70 \%, 50 \% \mathrm{v} / \mathrm{v})$, acetone $(100 \%, 70 \%, 50 \% \mathrm{v} / \mathrm{v})$ and water were used for extraction of polyphenols. At first, fresh samples $(0.5 \mathrm{~g})$ with $50 \mathrm{~mL}$ of solvents were shaken at room temperature for 1 hour. Then it was filtered through filter paper (Filtrak No. 392). Afterwards obtained extracts were analyzed. Another part of mixed samples were lyophilised and gained material $(0.5 \mathrm{~g})$ was extracted in the Twisselmann apparatus with organic solvents $(100 \mathrm{~mL})$ for 8 hours.

\section{Determination of the antioxidant activity (TAA)}

The antioxidant activity of sweet and tart cherry extracts was measured in terms of radicalscavenging ability, using the DPPH method (Brand-Williams et al., 1995).
The stock solution was prepared by dissolving DPPH with methanol, and then the working solution was obtained by mixing $10 \mathrm{~mL}$ stock solution with $90 \mathrm{~mL}$ methanol. Fruit extracts $(100 \mu \mathrm{L})$ were allowed to react with DPPH solution. The decrease in absorbance of DPPH at $515 \mathrm{~nm}$ was measured in intervals until the absorbance stabilised $(10 \mathrm{~min}$.). Results were expressed as the percentage of inhibition of free radical by present antioxidants.

\section{Determination of total polyphenol content (TPC)}

The total polyphenol content was assessed by the method of Lachman et al. (2003) employing the reduction of a phosphowolframate-phosphomolybdate complex to blue products by phenolic compounds. Briefly, an aliquot of the extract, blank or standard was placed in a $50 \mathrm{~mL}$ flask, where the Folin-Ciocalteu assay $(2.5 \mathrm{ml})$ was added and the mixture was allowed to react for $3 \mathrm{~min}$ under continuous stirring before a solution of sodium carbonate $(7.5 \mathrm{~mL})$ was added and mixed thoroughly. The volume was then made up to $50 \mathrm{ml}$ with distilled water and left standing at room temperature for 2 h. The absorbance was measured at $765 \mathrm{~nm}$ using Shimadzu UV-1800 spectrophotometer (Japan). Results were expressed as mg gallic acid equivalents (GAE) per $100 \mathrm{~g}$ fresh matter (or dry weight when calculating results of TPC of lyophilised tart cherries) 


\section{Statistics}

Data was analyzed with the programme Statistica (Statistica 6.0 CZ). All analyses were done in triplicate, and expressed as average values \pm standard deviation. Results were processed by using a one-way analysis of variance (ANOVA). Significance was determined at $p<0.01$ using t-test for correlating samples.

\section{RESULTS}

Analyses for surveying the effect of different solvents on the yield of extracted polyphenols from cherry fruits were carried out and evaluated. The solubility of polyphenols was highest in sweet cherry extracts with using of $50 \%$ methanol and $70 \%$ ethanol, followed by $100 \%$ methanol $\approx 70 \%$ methanol, $50 \%$ acetone, $50 \%$ ethanol, water, $70 \%$ acetone and $100 \%$ acetone. It seems that $50 \%$ and $70 \%$ solvents (except for ethanol) gave higher phenol yields than pure solvents or water (Figure 1).

On the contrary, the highest content values of phenolics were in tart cherries extracts when using of $50 \%$ acetone, followed by $70 \%$ acetone, $50 \%$ methanol, 100 $\%$ methanol, $70 \%$ methanol, water, $50 \%$ ethanol, $70 \%$ ethanol and $100 \%$ acetone.

Our results showed that $50 \%$ methanol as extracting solution is the most efficient solvent by sweet and tart cherry extracts. This solvent represents better experimental conditions for polyphenol analysis of tested fruits.

Interesting results were obtained by the extraction of tart cherry fruits samples with aqueous acetone which provided the highest yield of total phenolics. We suppose this is due to possible extraction of tannins that are responsible for a bitter taste of some fruits (mainly of tart cherries in this case) and which are soluble in acetone.
The total polyphenol contents (TPC) of tart cherries extracts were higher than those of sweet cherry ones and ranged from $70.7 \pm 8.46 \mathrm{mg}$ gallic acid equivalents (GAE)/100 g FW to $241.4 \pm 7.26 \mathrm{mg}$ GAE/100 g FW. Marinova et al. (2005) reported higher total polyphenols for tart cherries (429.5 mg GAE/100 $\mathrm{g}$ FW) as compared to the samples analysed in the present study. TPC of sweet cherry extracts were in range from $27.8 \pm 9.74 \mathrm{mg}$ GAE/100 $\mathrm{g} \mathrm{FW}$ to $105.8 \pm 10.5 \mathrm{mg}$ GAE/100 g FW. Marinova et al. (2005) assessed similar TPC in sweet cherries extracts (78.8 $\mathrm{mg} \mathrm{GAE} / 100 \mathrm{~g}$ FW).

Literature differs in TCP of sweet cherry extracts, from $23 \mathrm{mg} \mathrm{GAE} / 100 \mathrm{~g} \mathrm{FW}$ to $168 \mathrm{mg} / 100 \mathrm{~g} \mathrm{FW}$ (Vangdal and Slimestad, 2006), those reported by Usenik et al. (2008) ranged from 44.3 to $87.9 \mathrm{mg} \mathrm{GAE} / 100 \mathrm{~g} \mathrm{FW}$, while Kim et al. (2005) reported the average of four sweet cherry cultivars $110 \mathrm{mg}$ GAE/100 g FW. There could be some discrepancies when comparing foreign study works with ours due to various extraction solvents as well as various extraction conditions. There could be also many other factors influencing results, because the presence of polyphenols in various plant foods is greatly determined by genetic factors, environmental conditions, degree of ripeness, variety, etc. (Bravo, 1998).

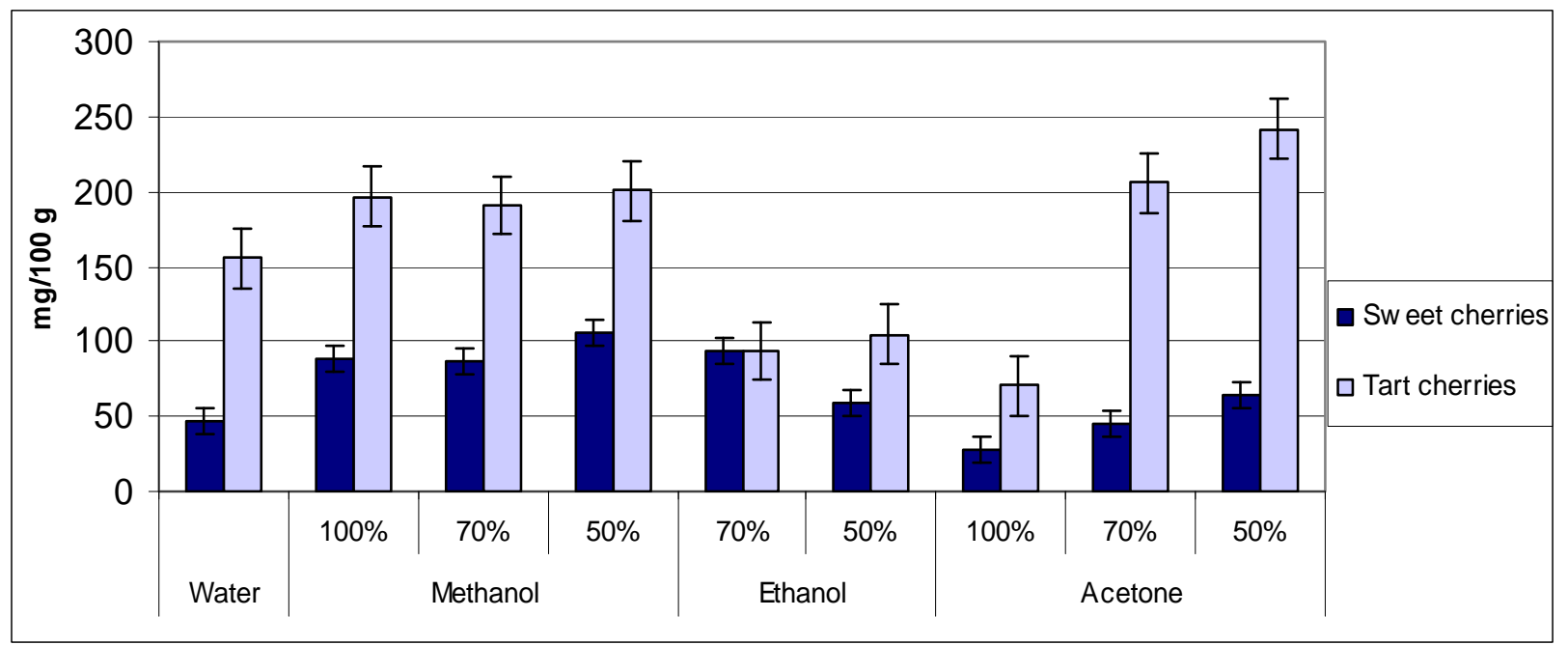

Figure 1: Comparison of total phenolics contents (TPC) in sweet and tart cherry extracts with different solvents. 
Tart cherry extracts (methanolic and water-acetone mixtures) contained in average 2-times higher amount of polyphenols than ethanol extracts (Figure 1). Water appeared to be better solvent for phenolics yield of tart cherry extracts in comparison to sweet cherry extracts. The best solubility of phenolic compounds was achieved in tart cherry extracts with $50 \%$ acetone and in sweet cherry extracts with $50 \%$ methanol.
Literature has also provided data about antioxidant profile in both fresh and lyophilised material. For this reason we decided to lyophilise tart cherry fruits and then to extract them by polar solvents $(100 \%, 70 \%, 50$ $\%$ methanol and $70 \%, 50 \%$ ethanol for 8 hours), because of the lack of sweet cherry fruits. Fresh material was also extracted for 1 hour Results were evaluated and compared with those from lyophilised tart cherries samples (Table 1).

Table 1: Polyphenol contents (mg gallic acid equivalent/100 g FW) in extracts of tart cherries with used polar solvents.

\begin{tabular}{|c|c|c|}
\hline Extraction medium & Extraction time/temperature & TPC in extracts of tart cherries, SD \\
\hline Methanol $100 \%(\mathrm{v} / \mathrm{v})$ & 1 hour/room temp. & $196.7 \pm 4.21$ \\
\cline { 2 - 3 } & 8 hours/room temp. & $165.3 \pm 2.03$ \\
\hline \multirow{2}{*}{ Methanol $70 \%(\mathrm{v} / \mathrm{v})$} & 1 hour/room temp. & $190.6 \pm 3.65$ \\
\cline { 2 - 3 } & 8 hours/room temp. & $134.9 \pm 0.25$ \\
\hline \multirow{2}{*}{ Methanol 50 \% (v/v) } & 1 hour/room temp. & $200.5 \pm 2.09$ \\
\cline { 2 - 3 } & 8 hours/room temp. & $166.4 \pm 5.21$ \\
\hline Ethanol 70 \% (v/v) & 1 hour/room temp. & $43.7 \pm 1.76$ \\
\cline { 2 - 3 } & 8 hours/room temp. & $46.3 \pm 2.45$ \\
\hline Ethanol $50 \%(\mathrm{v} / \mathrm{v})$ & 1 hour/room temp. & $104.3 \pm 5.67$ \\
\cline { 2 - 3 } & 8 hours/room temp. & $83.3 \pm 4.23$ \\
\hline
\end{tabular}

Values presented are means \pm standard deviation (SD) of triplicate analysis of each duplicate extraction.

When considering polar solvents and the yield of total phenolics in tart and sweet cherry extracts, methanol was obviously more efficient than ethanol in extracts from fresh and from lyophilised material.

Because of higher content of polyphenols in extracts of fresh material compared to lyophilised material, we can sum up that the assessment of the polyphenols in fresh material using $50 \%$ methanol is sufficient. The same results were mentioned by Timoracká et al. (2009) who determined similar results in redcurrants and raspberries. Total phenolics from tart cherry extracts were higher after 1 hour extraction using $50 \%$ methanol and $50 \%$ ethanol, compared to extracts of lyophilised tart cherries.

Antioxidative capacity is an important fruit quality parameter. The DPPH radical scavenging assay is commonly employed to evaluate the ability of antioxidant to scavenge free radicals. 


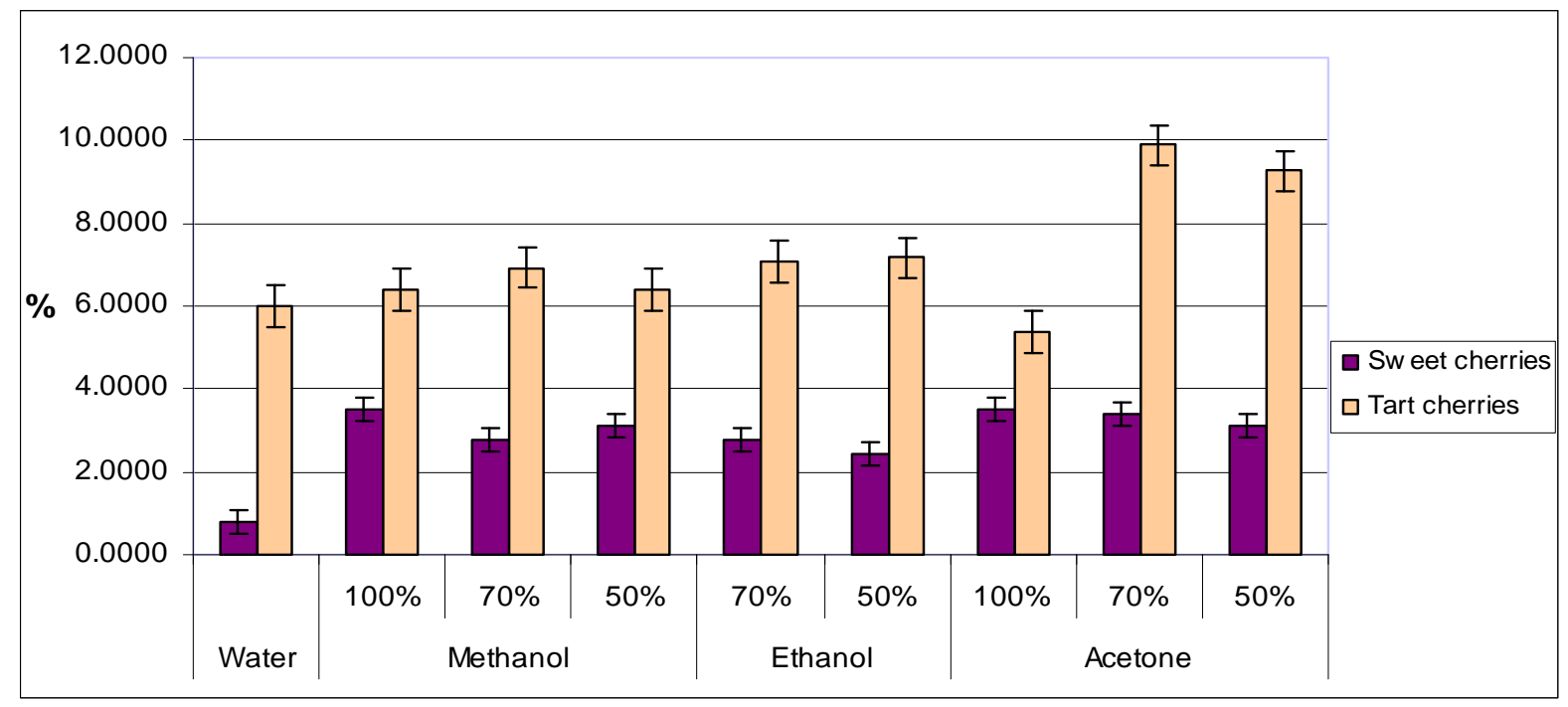

Figure 2: Values of total antioxidant activity (TAA) in extracts of sweet and tart cherry fruits with different solvents

The DPPH antiradical efficiency values of tart cherry extracts were higher when compared to sweet cherries (Fig. 2). Tannins released by acetone in tart cherry extracts also exert antiradical activity and it is obviously reflected in the inhibition of DPPH radical. Values of total antioxidant activity (TAA) of tart cherry extracts ranged from 5.4 to $9.9 \%$ of inhibition of DPPH.

Values of TAA were relatively high in tart cherries extracts with aqueous acetone and in sweet cherries extracts with pure methanol and pure acetone. The lowest inhibition of DPPH radical was determined in sweet cherry extracts using water and in tart cherry extracts using $100 \%$ acetone.
The relation between TPC and TAA was studied. The dependence of variables (TPC and TAA in sweet cherry extracts using $50 \%$ acetone was highly significant at $\mathrm{P}<0.05$. There was an inverse correlation between TPC and TAA in sweet cherry extracts $(r=-0.7233)$ using 100 $\%$ of acetone. Antioxidant activity in the case of sweet cherry extracts using $70 \%$ ethanol depends on phenolics. Analyzed TPC and TAA showed strong dependence in sweet cherry extracts using $70 \%$ methanol and in tart cherry extracts using $50 \%$ methanol. Contrary results were gained for tart cherry extracts, where positive correlation was found for 100 $\%$ acetone. Weak correlations were found between TPC and TAA in sweet and tart cherry fruit extracts using $100 \%$ methanol. 


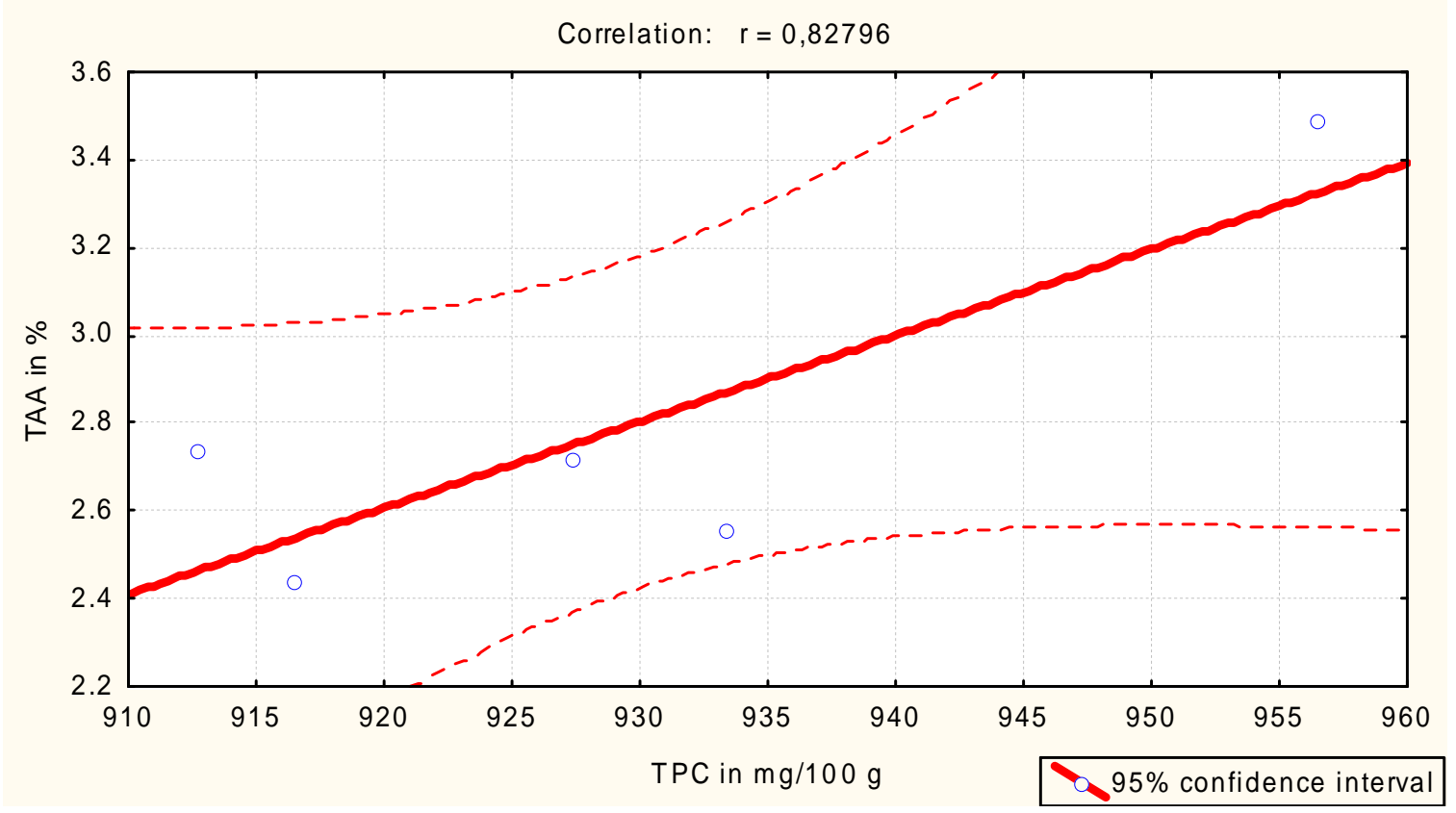

Figure 3: Relation of total phenolics (TPC) and total antioxidant activity (TAA) of sweet cherries extracts using 70 $\%$ of ethanol

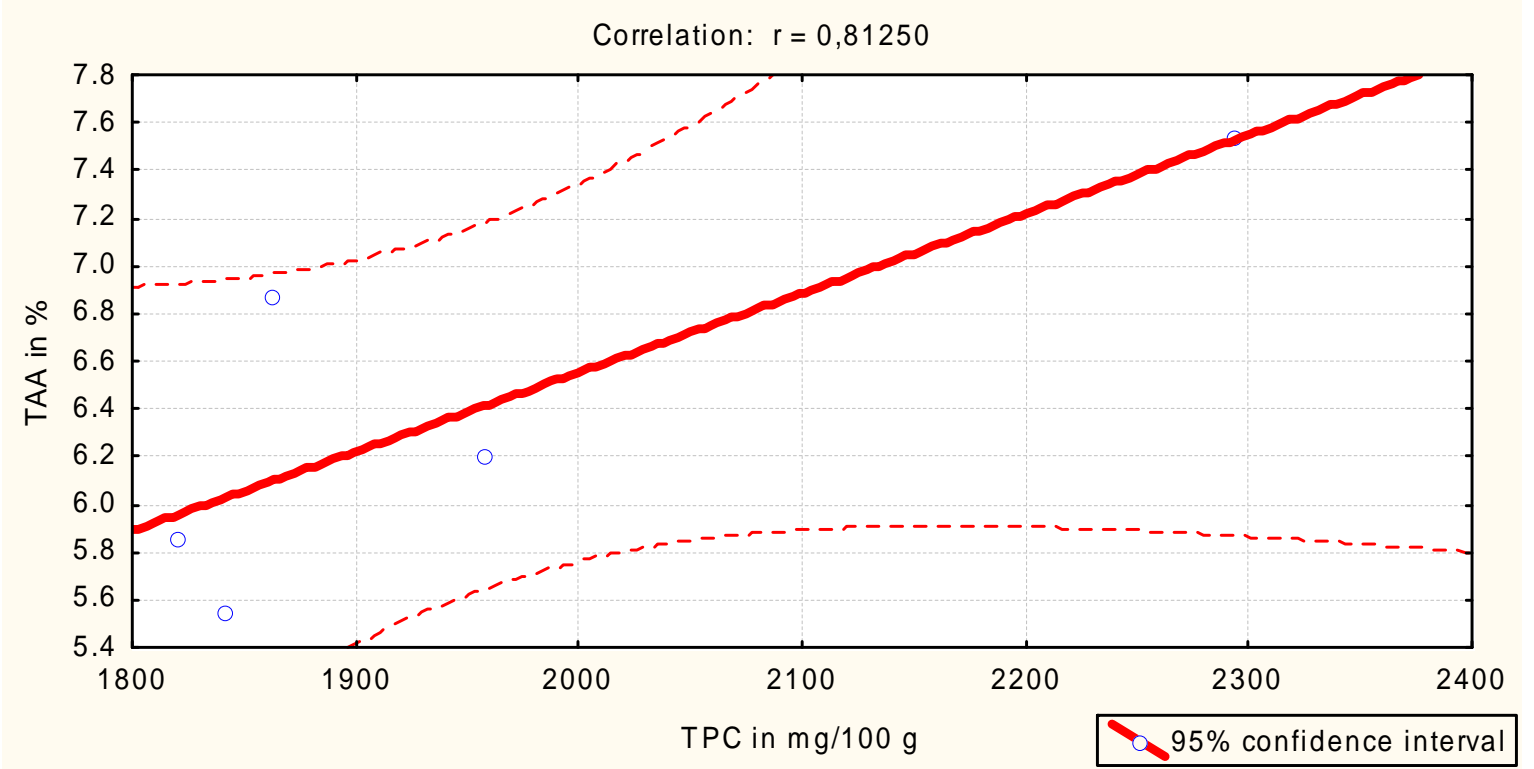

Figure 4: Relation of total phenolics contents (TPC) and total antioxidant activity (TAA) of tart cherry extracts using $50 \%$ methanol

Positive correlation of variables (TCP and TAA) in sweet cherry extract using $70 \%$ ethanol was evaluated at $\mathrm{P}<0.05$ (Fig. 3).
From the correlation analysis, it can be summarized that total phenolic content had positive correlation with antioxidant capacity in extracts of tart cherries using 50 $\%$ methanol (Fig. 4). 


\section{DISCUSSION AND CONCLUSION}

The highest extraction yields of phenolics were determined using $50 \%$ methanol in sweet cherry extracts. The most efficient extraction solvent in tart cherry extracts was $50 \%$ acetone. In our research, 100 $\%$ acetone has proved to be the least effective solvent for the gained yield of phenolics of both cherry extracts. Aqueous $70 \%$ acetone provided higher yield of polyphenols in tart cherry extracts in comparison to pure acetone, in spite that Rødtjer et al. (2006) reported that quantification of the total amount of phenolics in the extracts showed that $70 \%$ solvent-water mixtures extracted phenolics more efficiently than pure solvent extracts did. But, in our paper it is obvious that $50 \%$ solvent-water mixtures gave higher extraction yield than pure solvents.

The solubility of TPC of both tested cherry fruit extracts was higher with $100 \%$ methanol in comparison to 100 $\%$ acetone.

There were significant differences of TPC in both stone fruit extracts when evaluating the content values of one organic solvent, so we can sum up that the phenol contents of the extracts were dependent on the solvent used. Also Turkmen et al. (2006) have reported that the phenolics contents of extracts are strongly dependent on the type of the solvent as well as on different concentrations of solvent.

Our results showed that tart cherry extracts have substantial amounts of total phenolics which were higher than those of sweet cherry ones, what had reflected on the strong antiradical activity. This fruit can be considered in fresh state as good source of dietary phenols. Despite the TPC in extracts of lyophilised tart cherries samples were lower than those of extracts form fresh material, using of $50 \%$ methanol as extraction solvent for lyophilised tart cherry samples showed good extraction ability.

Total antioxidant activity (TAA) of sweet cherry extracts (with used $70 \%$ ethanol and with $70 \%$ methanol) and of tart cherry extracts (with $50 \%$ methanol) depended on phenolics content. This shows that both tested stone fruits are source of natural antioxidants.

However, further studies about relation of antioxidant activity and phenolics content are necessary also for other fruits.

\section{ACKNOWLEDGEMENT}

This research work was supported by KEGA 3/5081/07, VEGA 1/0030/09 and APVV SK-SI-0008-08.

\section{REFERENCES}

Brand-Williams, W., Cuvelier, M.E. and Berset, C. 1995. Use of a free radical method to evaluate antioxidant activity, Lebensmittel-Wissenschaft und Technologie 28: 25-30.

Bravo, L. 1998. Polyphenols: chemistry, dietary sources, metabolism and nutritional significance. Nutrition Reviews 56: 317-333.

Gao, L. and Mazza, G., 1995. Characterization, quantitation and distribution of anthocyanins and colorless phenolics in sweet cherries. Journal of Agricultural and Food Chemistry 43: 343-346.

He, F., Nowson, C., Lucas, M. and Macgregor, G. 2007. Increased consumption of fruit and vegetables is related to a reduced risk of coronary heart disease: Metaanalysis of cohort studies. Journal of Human Hypertension 09509240/07: 1-12.

Kalyoncu, I.M., Ersoy, N. and Yilmaz, M. 2009. Some physico-chemical properties and mineral contents of sweet cherry (Prunus avium L.) type grown in Konya. African Journal of Biotechnology 8: 2744-2749.
Kang, S.Y., Seeram, N.P., Nair, M.G. and Bourquim, L.D., 2003. Tart cherry anthocyanins inhibit tumor development in APC min mice and reduce proliferation of human colon cancer cells. Cancer Letters 194: 13-19.

Kim, D.O., Heo, H.J., Kim, Y.J., Yang, H.S. and Lee, C.Y. 2005. Sweet and sour cherry phenolics and their protective effects on neuronal cells. Journal of Agricultural and Food Chemistry, 53, 26: 9921-9927.

Lachman, J., Hejtmánková, A. and Dudjak, E. 2003. Content polyphenolic antioxidants and phenolcarboxylic acids in selected parts of yacon. In: Proceedings of Vitamins 2003 - Přírodní antioxidanty a volné radikály. Univerzita Pardubice, 89-97 p.

Marinova, D., Ribarova, F. and Atanassova M. 2005. Total phenolics and total flavonoids in Bulgarian fruits and vegetables. Journal of the University of Chemical Technology and Metallurgy 40, 3: 255-260.

Piccolella, S., Fiorentino, A., Pacifico, S., D'Abrosca, B., Uzzo, P. and Monaco, P. 2008. Antioxidant properties of sour cherries (Prunus cerasus L): Role of colorless

Acta agriculturae Slovenica, 95 - 1, marec 2010 
phytochemicals from the methanolic extract of ripe fruits. Journal of Agricultural and Food Chemistry 56: 19281935.

Rødtjer, A., Skibsted, L.H. and Andersen, M.L. 2006. Antioxidative and prooxidative effect of extracts made from cherry liqueur pomace. Food Chemistry 99:6-14.

Ruxton, C., Gardner, E. and Walker, D. 2006. Can pure fruit and vegetable juices protect against cancer and cardiovascular disease too? A review of the evidence. International Journal of Food Science and Nutrition 57: 249-272.

Seeram N.P, Momin R.A, Nair M.G. and Bourquin L.D. 2001. Cyclooxygenase inhibitory and antioxidant cyanidin glycosides in cherries and berries. Phytomedicine 8(5): 362-369.

Sellapan, S., Akoh, C. and Krewer, G. 2002. Phenolic Compounds and Antioxidant Capacity of Terbia-Grown Blueberries and Blackberries. Journal of Agricultural and Food Chemistry 50: 2432-2438.

Serrano, M., Guillen, F., Martinez-Romero, D., Castillo, S. and Valero, D. 2005. Chemical constituents and antioxidant activity of sweet cherry at different ripening stages. Journal of Agricultural and Food Chemistry 53: 2741-2745.

Seymour E., Lewis S., Urcuyo-Llanes, D. and Bolling S. 2008. The effect of tart cherry enriched diets on abdominal fat gene expression in rats. Journal of American Diet Association 108(9): A14 - A14.

Timoracká, M., Melicháčová, S. and Čéry, J. 2009. Determination of antioxidants in small fruit - comparison of methods. Acta fytotechnica et zootechnica (Special issue of Slovaca Universitas Agriculturae Nitriae) 1: 652660 .

Turkmen, N., Sari, F. and Velioglu, Y.S. 2006. Effect of extraction solvents on concentration and antioxidant activity of black and black mate polyphenols determined by ferrous tartrate and Folin-Ciocalteu methods. Food Chemistry 99: 838-841.

Usenik, V., Fabcic, J. and Štampar, F., 2008. Sugars, organics acids, phenolic composition and antioxidant activity of sweet cherry (Prunus avium L.). Food Chemistry 107: 185-192.

Vangdal, E. and Slimestad, R. 2006. Methods to determine antioxidative capacity in fruit. Journal of Fruit and Ornamental Plant Research 14: 123-131.

Wang H., Nair, M.G., Straburg, G.M., Booren, A.M. and Gray, J.I. 1999. Antioxidant polyphenols from tart cherries (Prunus cerasus). Journal of Agricultural and Food Chemistry 47: 840-844. 